\title{
研修医と現代のうつについて 一ゆとり世代の到来を踏まえた，現代的解釈と対応一
}

Mood Disorder of Medical Residents in Recent Era

- Considering the Characteristics of the Generation Educated with Latitude-

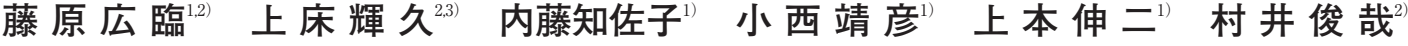 伊 藤 和 史 $^{1)}$ \\ Hironobu Fujiwara ${ }^{1,2)}$, Teruhisa Uwatoko ${ }^{2,3)}$, Chisako Naito ${ }^{1)}$, Yasuhiko Konishi ${ }^{1)}$, Shinji Uemoto ${ }^{1)}$, Toshiya Murai ${ }^{2)}$, Kazushi Ito ${ }^{1}$}

\section{要 旨}

近年，特に若年者においてうつ病が多様化し，医学教育の現場でも対応困難な場面を体験することは多い。本 稿では,「ゆとり世代」の特徵も踏まえたうえで若者のうつ病について概説し, 医学生・研修医のメンタル面で の初期対応に資する情報を提供する。

\begin{abstract}
In recent years, depression has become diverse, particularly in the younger population. In the field of medical education, it is assumed that a number of educators often experience difficulties in attending to their learners with depression. In this review article, information which contributes to the promotion of mental health for medical residents is provided, considering the knowledge of recent depression in the younger population, including its diversity together with the characteristics of the "generation educated with latitude".
\end{abstract}

Keywords：医学教育 (Medical education)，初期研修医（Residents），現代のうつ病（Mood disorder in recent era）, ゆとり世代 (Generation educated with latitude)

\section{1 はじめに}

近年，自殺事案等の問題もあり初期研修医（以下, 研修医）の労働管理の適正化が図られるようになった が ${ }^{1)}$, 依然としてうつ病等に関する報告は相次ぎ ${ }^{32}$, 指 導医が対応に労力を割くことも多い.

一方，若者を中心に，うつ病の「多様化」が指摘さ れている ${ }^{4,5)}$. 従来の内因性うつ病 (メランコリー型う つ病）は, 律儀 · 几帳面 ·模範的 · 自責的な病前性格 (メランコリー親和型性格)を有し, 食欲低下, 早朝覚 醒主体の不眠等が特徵的であったが, 現代のうつ病は, メランコリー型うつ病とは異なる色彩を持つ.

また，近年研修医として入職してくる世代をさす呼
称として「ゆとり世代」という言葉を聞くようになっ てしばらく経つ。ゆとり世代がどの年代を指すのかに ついては諸説あるが, 2002 年度施行の学習指導要領 (いわゆるゆとり教育) を受けた世代（1987 年度から 1995 年度生まれ)を指すことが多い.2011 年度以降, 小学校等の学校教育において改定がなされ, いわゆる 「脱ゆとり教育」に移行しているが，一部だけでもゆと り教育を受けた者, という定義に基づいた場合は, 2003 年度生まれまでを含む。本稿に扮けるゆとり世代も, この広義のものを指すものとする。

ゆとり教育を受けた世代が社会人デビューするに際 し, この特性も踏まえて若者のうつ病を再考し, メン

1) 京都大学医学部附属病院総合臨床教育・研修センター

2) 京都大学大学院医学研究科脳病態生理学講座 (精神医学)

3) 京都大学健康科学センター

著者連絡先：藤原広臨 京都大学医学部附属病院総合臨床教育・研修センター [テ 606-8507 京都府京都市左京区聖護院川原町 54] email: hirofuji@kuhp.kyoto-u.ac.jp

(受付日：2016年 6 月 7 日, 採用日：2016 年 10 月 20 日)

C)2017 日本プライマリ・ケア連合学会 
表 1 提唱されている「現代のうつ病」のまとめ

\begin{tabular}{|c|c|c|c|}
\hline & 特性 & 関与する性格 & 治療のポイント \\
\hline 逃避型抑うつ（広瀬） & $\begin{array}{l}\text { 慢性的, 状況から逃避, } \\
\text { 努力放棄 }\end{array}$ & $\begin{array}{l}\text { ちょっとした困難状況, } \\
\text { ヒステリー的, } \\
\text { 自己愛的, 弱力 }\end{array}$ & 特別な配慮で好転 \\
\hline 現代型（松波） & 制止, 当惑, 身体愁訴 & $\begin{array}{l}\text { 自己中心的, } \\
\text { マイペース重視 }\end{array}$ & $\begin{array}{l}\text { 心理面を受容し, 身体面の治療に } \\
\text { 力点, 生活リズム調整 }\end{array}$ \\
\hline 未熟型（阿部） & $\begin{array}{l}\text { 制止, 不安, 焦燥, } \\
\text { 躁うつ混合, 攻撃的, 行動化 }\end{array}$ & 攻撃的, 他罰的 & 自立促す精神療法 \\
\hline 職場結合性（加藤） & 不安強い & $\begin{array}{l}\text { や自己愛的だが, } \\
\text { 著しい問題はない }\end{array}$ & リハビリへの導入, 職場との調整 \\
\hline ディスチミア親和型(樽見) & $\begin{array}{l}\text { 不全感, 倦总感, } \\
\text { 罪亚乏しい }\end{array}$ & $\begin{array}{l}\text { 陰気，神経質，悲観的， } \\
\text { 自己批判的 }\end{array}$ & ほめて心的弾力性を樹立 \\
\hline 非定型 & $\begin{array}{l}\text { 過眠, 過食, 倦怠, } \\
\text { 状況反応性の気分変化 }\end{array}$ & 過敏で傷つきやすい & $\begin{array}{l}\text { 薬物療法も一定の効果がある場 } \\
\text { 合あり. }\end{array}$ \\
\hline
\end{tabular}

表 2 大うつ病性障害の診断基準 (DSM-5, 抜粋)

以下の症状のうち 5つ（またはそれ以上）が，ほとんど一日中，ほ とんど毎日にわたり，同じ2 週間の間に存在し, 病前の機能からの 変化を起こしている.これらの症状のうち少なくとも 1 つは (1) 抑うつ気分, または（2）興味または喜びの亦失である。これらの 症状は，苦痛または，社会的，職業的，またはほかの重要な領域に おける機能の障害を引き起こしている。 また,このエピソードは, 物質の生理的作用, またはほかの医学的疾患によるものではない.

(1) その人自身の言葉か, 他者の観察によって示される抑うつ気分

（2）ほとんどすべての活動における興味または喜びの著しい減退

（3）体重減少あるいは体重増加，または食欲減退あるいは増加

（4）不眠または過眠

（5）精神運動焦燥または静止

(6) 疲労感または気力の減退

（7）無価値観，または過剰であるか不適切な罪責感

（8）思考力や集中力の減退，または決断困難

（9）死についての反復思考, 自殺念慮, 自殺企図あるいは計画

タル面での初期対応・医学教育に資するべく考察して みたい.

\section{2 現代のうつ病概念の特徵}

「現代型・未熟型・非定型」等, 現代のうつ病の各概 念 $(\text { 表 1 })^{6)}$ は，差異はありながらも共通点を有する. それはすなわち, 他責的 - 自己愛的な病前性格, 身体 的症候としての過食 ·過眠, 抑うつ症状が場所 - 場面 選択的といったことに集約されるが，現代のうつ病の 捉え方としては下記 2 つ立場が考えられる.

(1)自己愛的な人格傾向，過眠・過食，他責的などの 症候を示し，メランコリー型とは異なるとする立場

(2)「見た目，印象」が時を経て変化しただけで，本質 的にはメランコリー型と同様の病態とする立場

現在の米国精神医学会の診断基準では, 表面的な症 候のみが取り上げられ7)(表 2), 病前性格等は考慮され ていないため，(1)と(2)の判別は困難であるが，ここで
はこの明確化は目的とせず論を進める.

(1)の利点は, 性格特性や過眠・過食等を考慮の上,

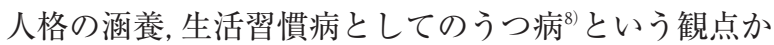
らの対応が可能となることにある。一方，(1)の弊害は， 各症候を元来の性格に帰することで, 治療困難との先 入観に陥ったり，指導の強要で本人との関係性を損 なったりする可能性があることである.

次に, (2)の利点としては, 軽症・サブクリニカルな メランコリー型うつ病を拾い上げることで, 自殺事案 等の防止に役立つという可能性が挙げられ, 弊害とし ては, 適応障害等の他の疾患をメランコリー型うつ病 との連続体でみてしまうことで, 不適切な治療方針を 選択する可能性が生じるということがある。このよう に, いずれも利点と欠点を有するが, 事故の防止とい う意味では，まずは内因 (メランコリー型うつ病) $\rightarrow$ 心 因（適応障害等）という思考過程が安易に前後しない ことが重要である. なお, 内因 $\rightarrow$ 心因の思考過程につ 
いては，研修医の言動・行動等をどのように評価・参 考にすれば鑑別できるかという点においてより詳細な 理解を要すると考えられる.内因性うつ病については, 早朝覚醒・中途覚醒主体の睡眠障害, 食欲不振㧍よび 体重減少といった身体症状を呈することが多く, 病前 性格としては過度に物事に対する責任感を感じてしま う傾向（すなわち, 自責的な病前性格）があり, 気分 が朝方に悪く, 夕方以降には改善傾向となるという日 内変動を呈する，などの症候が従来から想定されてき た典型例での特徵であり，この鑑別のためには，身体 面も含めた体調の確認や，自責的発言や日内変動の有 無は参考にすべき重要な事項である。一方，心因性う つ病は，これらの症候を備えないことが多い.しかし， これらの特徵が内因性うつ病のすべての例にあらわれ るわけではなく, 本稿の冒頭より述べてきている通り， 現代のうつ病の表現型は多様化しており, 従来想定さ れてきた内因性うつ病とは表現型が異なるタイプの, いわばマスクされた内因性うつ病が潜在的にはあると 考えるのが本章(2)の立場である. よって自殺等の深刻 な事案発生のスクリーニングとしては，まずは(2)の立

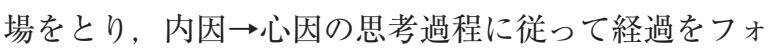
ローアップしていくのがより安全と考えられる.

\section{3 ゆとり教育と研修医のストレス}

一方, 内因 $\rightarrow$ 心因の順が重要ではあるが, 従来の内 因性うつ病を想定した対応, すなわち, 休養・薬物療 法にて快方に向かうという前提に立つ対応では困難な ケースも多々ある.この場合, 本人の病前性格や世相が 変わりゆく空気を感じつつ対応を考える必要がある。

これに関連する現代の若者の呼称「ゆとり世代」は, 下記のような特性を持つ ${ }^{9.10)}$.

(1)素直でまじめ

(2)自信がなく失敗を恐れる，評価を気にする

(3)個性重視

(4)短期間・即自的な結論を求める

(5)自身の利得・成長につながることを率先して行う

(6)マニュアル的な手本を好み, 応用は不得手

(7)コミュニケーションが苦手

8)打たれ弱い

近年入職してきている研修医と接するにあたり, 円 滑に相談にのり効果的にメンタルケアを行っていくた めには，まずは良好な相互の関倸を構築していくこと が必要である。 そのためには, 実際に, 近年の研修医 の年齢層はゆとり世代と一致するため，この特性を考 慮した対応が有用だと考えられる。
ゆとり世代の上記の特性に周囲はしばしば困惑させ られると思われるが, 一方, ポジティブな解釈も可能 である，例えば，慎重さ・評価を気にする傾向は仕事 の正確さに, 早期・即時の答えを求める傾向は, 明確 化された業務については成果が期待しやすいというこ とにつながりうる.「コミュニケーション能力不足・打 たれ弱さ」も, 経験を積めば段階的に成長可能, と捉 えられるかもしれない.ゆとり世代の特徴の背景には, 個性重視の教育, Face-to-Face のコミュニケーション や叱責される経験の減少等が推察されるが, これらは, 経験不足, 傷つきやすい自己愛等と解积されよう。だ とすれば，個性やプライドを尊重し，丁寧かつ理論的 に, 段階的には, 対人葛藤場面に扔ける問題解決等の 経験を積み，健全な自尊心を育むように指導するのが 理想的だと考えられる.

しかし, 教育場面での指導者と学習者との関わりは, それそのものが対人コミュニケーション場面である. 関倸性次第で教育者側に生じる感情やストレスマネー ジメントにも十分な配慮がなされるべきであるが，そ の意味でも上記の特性の把握は有意義である。なぜな ら, 知識・心理面での「備え」をすることで, 生じる 問題が指導医にとっては想定内の範囲に収まり, 指導 医自身の心の中での処理が可能となることが見込める からである，備えあれば憂い「少なし」程度になるこ とは期待できよう。

そもそも, 多忙さという点では指導医の方が厳しい 状況におかれている可能性はあり, 指導医の抑うつに 関する報告もある ${ }^{3)}$ ，しかし，注目すべきは，達成感・ 自己裁量度の低さ ${ }^{11}$, 頻繁に新たな人間関係を構築し ていく必要性 ${ }^{12)}$ といった, 研修医特有のストレスであ る. 指導医が, 研修医の幾分過度な自己愛やコミュニ ケーションスキルの問題を感じる場面もあろうが, こ れらの個性の偏りというべき特徴は, 指導医側が適切 な関わりを考える手がかりになるものと捉えていくの が建設的と考えられる。

一方, 表 1 にて示す, 現代に多いといわれるタイプ のうつ病と、ゆとり世代の特徴とを比較すると,いく つかの類似点があることがわかる. 従来のうつ病の典 型例では, 病前性格は自責的, 治療論的には休養第一 とし, 薬物療法を十分に行うことで宽解が得られやす いとされてきたが, 現代に多いとされる表 1 の種々の うつ病で見られる特徴としては, (1)病前性格上は多責 的・未熟・自己愛的な場合も多いこと(2)治療上は, 薬 物療法のみでは症状改善が不十分で，自立を促すよう なサポートや，心的弾力性を涵養する（すなわち，打 
たれ強さを育む）といった，教育的アプローチや，漫 然と休養を促すばかりではなく, 規則正しい生活習慣 を推奨したりすることも必要であるということがあ る.このように, ゆとり世代の(1)〜8)の特徴の中でも, 「自身がなく, 評価を気にする, 失敗を恐れる, 個性重 視，（根気よく自主的に物事に取り組むというよりも, やや受け身的に)即時の成果を求める，打たれ弱い」と いった特性は, 個々のケースによりばらつきはあるに しても, 現代に多い夕イプのうつ病における病前性格 （自己愛的，自己中心的，過敏で傷つきやすい)や，こ れに対応する治療上の特徴（配慮・職場での調整の必 要性, 自立を促す, 心的弾力性の樹立）と符合する部 分があると考えられる. したがって, 現代のうつ病患 者のすべての例でゆとり世代の特徴を認めるわけでは なく,「2 現代のうつ病概念の特徵」で述べたような, 従来型の内因性うつ病（メランコリー型うつ病）に合 致する例もあるにせよ, 現在の研修医を含む若年者の うつ病については, ゆとり世代の特性を踏まえた上で の対応をすることが望ましい. 従来は, うつ病といえ ばメランコリー型うつ病であり, その病前性格といえ ば「律儀・几帳面・模範的・自責的」(メランコリー親 和型性格)であると画一的に考えられていた。しかし， 表 1 に見られるように, 現代のうつ病の病前性格は変 容し, 従来のうつ病の病前性格一辺倒ではなくなった。 すなわち，非メランコリー型うつ病が増えたというこ とであるが, 非メランコリー型うつ病は, 比較的軽症 ながら完全寛解に至らず慢性化することも多く, 関わ る者を恼ませることが少なくないことからも，注目さ れるようになったのである ${ }^{13}$. ゆとり世代がうつ病発 症の直接の危険因子とまではいえないにせよ, 上述の 通り, 現代のうつ病の病前性格とゆとり世代の特徵と の間には類似点が多い. よって, 研修医のうつ病の対 応に扔いては, 特に従来型のメランコリー型うつ病の 病像を取らないケースでは, 相談者たる研修医との関 係づくりに始まる一連の対応の中で, この点を常に念 頭に置いておくことが有用になると考えられる.

\section{4 現場における抑うつ状態に対するケア・指導 について}

一般に「困難な学習者」の問題としては, 知識の不 足, 態度・行動面の問題（無責任, 感情のコントロー ル不良等 ${ }^{14}$ が挙げられるが, うつ病を含めた心身の不 調はこれらに悪影響を与える。 ただし, 経験により克 服されることも多く，休養が必要だと即断するのでは なく，現場での「On the job」トレーニングを続けなが
ら,「働きながら学習し・治す」という思考過程は重要 である. 抑うつ状態（うつ病および，うつ病の診断基 準を部分的にしか認めない程度の抑うつ)への対応上， 休業すべきか, 働きながら治すべきかの判断について, まず考慮すべきは, 本人の就労継続の意思, であろう． 十分な就労意欲があるにもかかわらず，本人への情報 提供等もなく, 指導医を含む周囲の関倸者のみで秘密 裏に方針が決まってしまうようなことがあれば，本人 の自尊感情を損なうなど, 指導医と研修医の信頼関係 に影響する可能性がある。しかし，最も重視されるべ きは, 現場での医療安全面の観点から, 本人が的確に 就労 (研修) でき, 医療安全が確保できる状態かどう かの客観的な見極めではないだろうか. 換言すると， うつ状態としての重篤さということにもなるかもしれ ないが, 例えば, 著しい不眠や思考力・集中力の低下 のため, 実際に無断遅刻・欠勤や診療場面でのミスが 著しく増えていたり, 本人が過度な自責感を背景とし て「周囲に報いるために」就労継続を申し出ていたり， あるいは，希死念虑を示唆する発言が聞かれていたり する場合には, 本人の研修継続の意思がいかに強固で あろうとも, 医療現場のインシデント防止のためには, 勤務軽減という段階を踏むことこそあれ, 休養もやむ なしであり, 本人の体調回復も就労要件のひとつ, と いう指導が妥当であると考える. 一方, 本人の就労意 欲が損なわれている場合には, 二つの可能性が考えら れる. そのひとつは, うつ状態として重篤であるとい う可能性である. 現場での量的・質的負荷を再度見積 もり, 就労量を調整するとともに, 本章にて上記述べ てきたように，それまでにはなかったような遅刻・欠 勤・ミスが著しく目立つ場合や, 自責感・希死念慮を 認める場合, 睡眠・食事その他の体調管理面での不調 が明らかな場合には, 勤務軽減や，休養・治療を考慮 すべきであろう。もうひとつの可能性は, 就労意欲を 欠くが，明らかなその他の症候は伴わず，めまぐるし くローテーションしていく中での新たな環境への適応 という点に扔ける主観的な困難さや, 新たな手技の取 得等に対する不安・自信のなさが就労意欲低下につな がっている場合である。この場合は，指導医がいわば 伴走するかたちで就労継続するなかで, 本人が達成感 などの手応えをつかんでいくプロセスを支援するのが 望ましいものと考える. なお，いずれにしても判断困 難な場面に際しては, 指導役は一人で孤立して抱え込 みすぎることのないように, 専門医も含む複数の関係 者で情報共有していく中で意思決定に至ることが望ま しいと考えられる。 
前述の通り, 研修医においては「自己裁量の範囲・ 達成感の少なさ」が特徴的である ${ }^{11}$. このため, 働きな がら経験を積み, 評価・承認を受け, 健全な自尊心を 育むことがメンタル面での初期対応という観点からは 有用で,「働きながら」そのものが治療的となりうる. しかし，そこで杓子定規に「では，休ませなければい い」とするのも安易であり, 潜在的な内因性うつ病の 見落としにつながりかねない。

その意味では, 方法論的な工夫（例：担当患者を減 らすがゼロにはしない等) が重要で, 治療者との連携 を密にし, 就労内容について共同で検討する等の対応 が有用になる. また, 教育者にとって, 相談者に対し て共感的に接することは必須ではあるが, 同時に客観 的な態度を堅持できることも必要で（突き放した関心 [detached concern]), 日々の研修医との関わりや指導 医自身のセルフモニタリングに役立つと考えられ $3^{15)}$.

\section{5 抑うつ状態を呈するうつ病以外の疾患および, これらとうつ病の併存について}

抑うつ状態を呈する精神疾患はうつ病以外にもある が, 抑うつ状態の程度として, 表つのうつ病の診断基 準を満たす場合もあればうつ病の診断の閾值下のもの もあり,多岐にわたりつつ併存症としても重なり合う。 抑うつ状態の中でも, これらの併存症を認める場合に は, より病像が非定型的で複雑であることが多いため, 教育者が対応に苦虑する可能性が高いと考えられる。 特にここでは, パーソナリティー障害, 自閉スペクト ラム症について述べる.

\section{5-1 パーソナリティー障害}

パーソナリティー障害は 3 つの群に分類され, 【A (妄想性, スキゾイド, 統合失調症型), B (反社会性, 境界性, 演技性, 自己愛性), C (回避性, 依存性, 強 迫性)】の 3 つの群がある。この中で, A 群は統合失調 症様の特徵, すなわち, 幻覚・妄想等の精神病症状と の関連が問題となり, うつ病という本稿の趣旨との関 連は薄いためここでは話題としない。一方, 抑うつを 呈しやすく, かつ, 感情的に不安定な特徵をもつ B 群の対応で困惑する場面は多いものと考えられる，B 群には, 反社会性・ (過度な) 自己愛性といった, 感情 の制御という点において人格的に成熟することへの困 難を抱える者が含まれるが, 表 1 に見られるうつ病の 病前性格のなかでも, 自己愛的・他罰的な部分と符合 する. 無論, 現代のうつ病にB 群のパーソナリティー 障害が必ず併存するわけではないが, 併存例は難治で
あることが多いということは経験論的に言われてお り, 独善的で他者を心理的に操作する, 見放されるこ とへの不安, 激しい感情の起伏等の特徴をもち, アン プロフェッショナルな振る舞い（周囲とのトラブルを 抱えるなど）が見られる場合もある。 このため, 教育 者側に陰性感情を惹起する可能性もある。このような 場合, 一人で抱え込まず, 専門医, 心理士など, 複数 のサポートを得ながらの対応が望ましく, あまりに独 善的で社会規範から外れる振る舞い等には毅然とした 対応も必要である. 様々な事柄に関して, 約束事(例： 社会人としての責任をもつこと等）を取り決めるなど の「枠組み」を共有し，このような「限界設定」の範 囲内でのサポートをしていくという姿勢は必須であ る.ただし, 根本にはサポート体制の保証という安心 感も重要で, 教育担当者・部署が嫌悪や怒りといった 陰性感情を募らせるのではなく, いわば「安全基地」の 機能をもつべきであると考えられる.C 群については, 回避性, 依存性パーソナリティー障害の傾向は, ゆと り世代の特徵（失敗を恐れる, 評価を気にする, 過敏 で傷つきやすい, 打たれ弱い＝回避性, 面倒を見ても らいたいという過度な欲求, 根気よく自主的に物事に 取り組むというよりも，やや受け身的に即時の成果を 求める =依存性）と符合する，パーソナリティー障害 の診断は従来からなされており, 特段ゆとり世代に 限ったわけではないし, 本稿は, 決して, ゆとり世代 =パーソナリティー障害ということを主張するもので もない。しかし， B 群であれ $\mathrm{C}$ 群であれ，パーソナリ ティー障害の併存が考えられる抑うつ状態のケースに おいては, 現代のうつ病扔よびゆとり世代の特徽を踏 まえることで病像が理解しやすくなるとともに, 日々 の対応という点でも有用となるようなケースがあると 考えられる.

\section{5-2 自閉スペクトラム症}

自閉スペクトラム症の本質は生来の自閉傾向であ り, 社会的な文脈を理解し適切なコミュニケーション を行うことに関する障害である. 言語の意味を字義通 りにとらえたり，他人の意図や信念を理解することが 苦手であったりすることで, 結果的に「空気を読めな い」ことからミュニケーションエラーを生じやすい. このため, 二次的に自己評価の低下，ひいては被害的 心理を伴う抑うつ状態に陥ることがあり,本質的には, 疾患特性への理解及び自覚が必要となる. 教育者に とっては, 個々の思考や行動のパターンを理解し,「構 造化」すなわち，枠組みを作ることが重要となる．押 し付けにならない程度に, 遂行すべき項目を明確にす 
ることで安心感をもたらし, 判断困難等による混乱に 伴う失敗を減少させることが二次的な抑うつの予防に 有用である. 自閉スペクトラム症は, 生来の特性と考 えられており, したがって, その発症そのものと, 教 育といういわば環境因と産物としてのゆとり世代との 直接の因果関係は考えにくい. しかし, 二次的な自己 評価の低下や被害的心理に伴う抑うつ状態を呈した場 面においては, 現代のうつ病の特徴の中での「不全感・ 過敏で傷つきやすい」といった症候が部分的に重なり 合うことがある。 このため, 現代のうつ病に関する理 解は, 自閉スペクトラム症を伴う抑うつ状態への対応 上役立つと考えられる.

\section{6 対応例}

以上，ここまでの内容を踏まえ，自験例の改編をも とに対応例を提示する.

$\mathrm{A}$ 研修医は，うつ病にて研修中断・通院開始となっ た後, 日常生活レベルでは症状は改善し, 職場復帰し た. しかし, 指導医や同僚に協力を依頼することが困 難で, 負荷が増えることへの不安が強く, 症状は再度 悪化した.「人付き合いは元々苦手. 教本とかあればい いのに，誰かが代わりに（言いにくいことを）言って くれたらいいと思う」等と語った。一方, 趣味や自身 の学習には集中でき，過食・過眠が目立った。

- 対人交流への苦手意識, マニュアルを求める傾 向：社会人経験の不足ゆえ，という解釈もありうるが， 研修医が指導医らに対して率直な意見を述べにくいと いう心情は理解可能とも考えた．このため，教育者は 指導医と情報を共有し，諸調整を行った，結果，担当 患者数の制限等の杵組みが共有でき, 本人の不安は軽 減した。 また, 対人交流の能力向上に関しては, これ までの経験や, 新たに得られる情報を応用する力を育 む必要があると考えた。苦手意識は受容しつつも，利 害関係のない友人の意見を参考にしたり, 病棟にて困 難であった対人場面を話題として問題解決のヒントを 出しあうなど，共に解決法を考えていくという関わり であった。

・抑うつが職務場面に限局する傾向：職務上の不全 感が強い中, 不安や自尊心を職務外の活動によって代 償しようと試みるのは共感可能と考えた。 これらの活 動による心理的な充実感は承認する一方, 就労復帰を 目指すこととの連続性も見出していくように努めた。

- 過眠・過食という身体的兆候：心理面の苦悩は受 容しつつ, 身体面では, 生活習慣病という捉え方から, 極力, 規則正しい生活リズムを保つという目標を共有
した.

このような関わりの中, 徐々に本人が自信を取り戻 していき，無事，研修修了となった。

\section{7 おわりに}

以上，ゆとり世代の特徵も踏まえ, 現代の若者のう つ病への対応について概説した.

今後の研修医や医学生の教育に参考となる部分があ れば幸いである。

\section{利益相反}

開示すべき利益相反はなし.

\section{文 献}

1）塚田真紀子．研修医の「うつ」を救えるか，こころの科学. $2006 ; 129: 2-9$.

2）久村正也. 医師のストレスーストレス状況，抑うつ傾向， 燃元尽き状態の男女医差. ストレス科学. $1997 ； 12(1)$ ： 61-64.

3）藤信明，上村宏，谷口弘毅，他. CES-D スケールを用いた 研修医に対するメンタルヘルスケアの試み。京都府立医 科大学㵶誌. $2009 ; 118(8): 543-549$.

4）傳田健三. 若者の「うつ」一新型うつ病」とは何か. 台東 区: 筑摩書房 ; 2009. 191.

5）吉野聡, 松崎一葉. 精神科産業医が明かす 職場のメンタ ルヘルスの正しい知識改定版. 千代田区：日本法令； 2011. 191-195.

6）医学臨床エキスパート 多様化したうつ病をどう診る か. 野村総一郎編. 文京区：医学書院；2011. 13-14.

7） DSM-5 精神疾患の診断・統計マニュアル. 高橋三郎, 大 野裕監訳：日本精神神経学会監. 文京区：医学書院； 2015. 160-161.

8）井原裕. 生活習慣病としてのうつ病.千代田区：弘文堂; 2013. 262.

9）井出芳美. 実践! ゆとり世代への支援指導教育の効果的 アプローチ. 看護実践教育. $2012 ； 9(4) ： 2-6$.

10）門千歳, 金田みどり, 緒方由美子, 他. 新人看護師教育の 再構筑一「とり世代」の特徽を踏まえて. 看護主任業務. $2013 ; 22(4): 35-40$.

11）木村环磨, 前野哲博, 小崎真規子, 他. 我が国における研 修ストレス反応とストレス緩和要因の探索执よびストレ ス理論モデルの作成. 医学教育. $2008 ； 39: 169-174$.

12）道喜正太郎, 吉野聡, 笹原信一朗, 他. 卒後臨床研究必修 化の前後に抢ける研修医のメンタルヘルスの変化に関す る検討. 医学教育. $2008 ; 39: 381-386$.

13）現代うつ病の臨床 その多㥞な病態と自在な対処法. 神 庭重信，黒木俊秀編．創元社；2012. 3-6.

14) Steiners Y. The "problem": Whose problem is it? AMEE Guide No 76. Medical Teacher. 2013; 35(4): 1035-1045.

15) Lief HI, Fox RC. Training for "Detached Concern" in medical students. Hoeber Medical Division; 1963. 12-35. (Lief HI, ed. The Psychological Basis of Medical Practice, By 52 Authors.) 